\title{
Process of adoption communication openness in adoptive families: adopters' perspective
}

\author{
Maria Acciaiuoli Barbosa-Ducharne* and Joana Soares
}

\begin{abstract}
Communication about adoption is a family interaction process which is more than the simple exchange of information. Adoption communication can be characterized in terms of the level of openness of family conversations regarding the child's past and the degree of the family's adoption social disclosure. The objective of this study is to explore the process of adoption communication openness in Portuguese adoptive families by identifying the impact of variables related to the adoption process, the adoptive parenting and the adoptee. One hundred twenty five parents of children aged 3 to 15, who were adopted on average 4 years ago, participated in this study. Data was collected during home visits using the Parents Adoption Process Interview. A cluster analysis identified three different groups of families according to the level of adoption communication openness within the family and outside. The findings also showed that the process of the adoption communication openness started when parents decided to adopt, developed in parent-child interaction and was susceptible to change under professional intervention. The relevance of training given to prospective adopters and of professional practice based on scientific evidence is highlighted.
\end{abstract}

Keywords: Adoption, Communication openness, Communication process, Adoptive parenting, Adoption professional intervention

Adoption is a way of growing a family which is ever more on the rise. In Portugal, every year, about 400 children are legally adopted and around 500 are placed in selected adoptive families, in order to be legally adopted by them in the near future. In this way, it can be said that adoption is the third highest chance that a child has to quit the Portuguese welfare system, of which he/she has been a part of, ever since his/her birth family was proven incapable of providing for, in terms of his/ her overall development. Presently, 8470 Portuguese children and youngsters are in residential or foster care. This number represents $0.36 \%$ of the overall population under the age of 18 (Instituto de Segurança Social, Instituto Público [Institute of Social Security, Public Institute] (ISS, IP, 2015). Only $8.7 \%$ of these children can eventually leave out-of-home care in order to be adopted. Nevertheless, for each adopted child, there is a possibility of growing up in an environment which fits

\footnotetext{
* Correspondence: abarbosa@fpce.up.pt
} Universidade Do Porto, Porto, Portugal his/her needs and features. It is, therefore, essential to assure that all the families who are given a chance to adopt should be able to overcome the challenges which adoption presents.

\section{Background}

Since 1980, Portuguese professional intervention in adoption has been regulated by law (Decreto-Lei [Act] 274/80). The consecutive changes of the Portuguese juridical adoption regime (Decreto lei [Act] 185/93, 22 May, Decreto Lei [Act] 12/98, 8 May e Lei [Law] 31/2003, 22 August) have led to different professional practices. Interventions, which were solely centered on the assessment and selection of prospective adopters, evolved into more complex interventions including training and preparation for adoptive parenting, as well as the required follow up during the family adaptation phase (officially during 6 months prior to legal adoption) and isolated post-adoption interventions. The Plan for Training in Adoption [Plano de Formação em Adoção] 
for prospective adopters started being systematically implemented in 2010 (Departamento de Desenvolvimento Social e Programas [Department of Programmes and Social Development] do ISS, IP, 2014). The training for adoptive parenting which has been provided for adopters in six small group sessions prior to the child's arrival, aims to reflect the specific needs surface along the adoption process. These needs relate to the definition of a realistic adoption project. The training for adoptive parenting works on the adopters' motivations and decision-making, as well as, the development of a secure attachment to the child and the boost of an open family adoption communication. This structured training, according to guidelines common to all national adoption agencies, shares all the goals that Sequeira and Stella (2014) specify for Brazilian Groups for Adoption Support [Grupos de Apoio à Adoção], namely the development of positive parenting.

In fact, professional intervention has evolved across the years and has become obvious in the new law on the juridical adoption statute which was primarily approved a while ago (Presidência do Conselho de Ministros [Board for the Council of Ministers]). This legal bill acknowledges the compulsory natures of adopters' training, proposes listening to the child's voice and his/her adoption preparation, besides recommending public post-adoption services both for children and parents.

Even though the Portuguese law on adoption is relatively progressive in relation to Children's Rights, adoption is still socially discriminated as the second best option of having children. Genetics and the bloodline itself are considered the priority regarding family bonds and it is common to single out adopted children from biological ones. An intergenerational study including grandparents, parents and children within the same family, supplied different notions of adoption. Grandparents found it difficult to acknowledge adoption specificities and rated the bloodline more highly (Barbosa-Ducharne \& Barroso, 2012). Furthermore, grandchildren, children and adolescents, reported situations in which they felt differential and discriminative treatment as adoptees, both within the extended family, and in other social contexts. As stated by Merçon-Vargas et al. (2014), the social principles and beliefs about adoption influence the adoption process and the meaning it has for adopters. Considering adoption in Brazil, Maux and Dutra (2010) refer a social image rooted in a bloodline culture deeply connected to a troublesome view of the adoptee and the consequent secrecy of adoption, including the myths and fears related to adoption disclosure and communication.

Current international research on adoption (cf. Palacios \& Brodzinsky, 2010 for a complete review) opens way for a completely different attitude in this respect. Adoption has been acknowledged as a successful natural intervention for children who have suffered early adversity, thus, allowing for total or partial developmental recovery (van IJzendoorn \& Juffer, 2006). Likewise, the quality of the adoptive family's experiences is a key factor in this recovery (Juffer et al., 2011) and adoption communication is essential to specific adoptive family dynamics (Brodzinsky, 2005).

Adoption communication evolves along the family lifespan and is crosswise to all adoptive families, notwithstanding the age of the adoptee's placement. Adoption must be revealed to adoptees who were adopted as infants or toddlers. Also, later adoptions require close-knit family communication about the child's recollections, in order to allow for the child's understanding and meaningfulness (Palacios, 2010). Howe and Feast (2003) pointed out that parent-child communication was more difficult in later adoptions than in earlier ones.

It is well known that the adoption communication process should begin as early as possible after the child's arrival, or rather, at 2 to 4 years of age when the child was adopted as an infant (Brodzinsky et al. 1984; MacIntyre, 1990). The adoption story, which is initially quite simple, becomes more and more complex and thorough according to the child's cognitive and emotional skills (Brodzinsky, 2011; Brodzinsky et al., 1984). The adoption concept is abstract and refers to a social entity. As the child has an opportunity to experience or talk about adoption, he/she will gradually construct a more complex conception of what it is (Barbosa-Ducharne et al. 2011).

Wrobel et al. (2003) propose a theoretical descriptive model of the development of adoption communication within the family. According to this same model, the adoption communication process develops along three different phases. As such, adoption communication evolves from a phase in which the adopters give their children unsolicited information and control the quantity and quality of the information that is shared. In the next phase, adopters answer to the child's curiosity, which focuses on different aspects, according to the child's development. In the third phase, the adoptee takes on control of the information which he/she considers necessary. At this stage, the child is proactive in satisfying his/her own curiosity. The openness of the shared communication in each phase is different from family to family (Barbosa-Ducharne et al. 2015).

Kirk (1964) first identified two family patterns which differ according to the recognition of the adoption specificities, highlighting the relevance of open communication between adopters and adoptees. Parents who rejected adoptive family specificities avoided talking about the adoptees' origins and showed less empathy towards the child's birth family. Parents who acknowledged the 
adoption specificities accepted the adoptee's connection with both families, and empathised more with his/her birth family. This last family pattern predicted a more positive family dynamic. Later on, Brodzinsky (1990) showed that some parents exaggerated in acknowledging the adoption specificities by insisting on the differences specially when facing conflicts. In these cases, the message that was put across focused on the adoptive status as a problem for the family (Palacios \& Sanchez-Sandoval, 2005). Thus, parents' attitudes should vary across different moments of the family lifespan. Sometimes, it is necessary to reject or minimise the adoption specificities, while in other situations, it is better to acknowledge the existing differences (Brodzinsky 1990).

In 2005, Brodzinsky defined the openness of adoption communication as "a willingness on the part of individuals to consider the meaning of adoption in their lives, to share that meaning with others, to explore adoption related issues in the context of family life, to acknowledge and support the child's dual connection to two families" (p.149). Later on, he (Brodzinsky, 2006, 2011) and other authors (e.g. Grotevant et al. 2005; Le Mare \& Audet, 2011) elaborated on this concept as well. Adoption openness communication is not simply the exchange of information but rather that of adoption related affective attunement, sharing, acceptance, emotional expression and coconstruction of meanings (Brodzinsky, 2005, 2006). The degree of openness of adoption communication is a result of reciprocal influences between parents and children. Nevertheless, following a developmental perspective, it is supposed that the parents' attitudes and behaviours create the initial context which promotes the subsequent openness on behalf of the child (Le Mare \& Audet, 2011). In this way, adoption communication openness is not a static characteristic of the family but rather a dynamic one, which can be developed in the parentchild interaction.

The available empirical evidence confirms the hypothesis that more open communication patterns are, both, associated to higher satisfaction regarding adoption (Howe \& Feast, 2003) and adoption communication (Wydra et al. 2012). These same communication patterns also promote more confidence in adopters (Kohler et al. 2002) and are related to secure attachment to adoptive parents (Farr et al. 2014), as well as a stronger psychological adjustment of adopted adolescents and adults (Grotevant et al. 2011; Levy-Shiff, 2001). Adopted children and adolescents, within these more open communication patterns, also show more psychological adjustment and self-esteem (Barbosa-Ducharne et al. 2012; Brodzinsky, 2006; Hawkins et al., 2007; Neil, 2009).

Further to the adoption communication openness within the family, it is also important to disclose adoption to the outside world. Even though there is scarce evidence on this subject, the openness to the outside world can contribute to a society in which family diversity will be more accepted and in which the adopted child will feel like "a normal human being belonging to human diversity” (Palacios, 2012, p. 89).

The present exploratory study aims to characterise the communication openness process, following the parents' perspective, within and outside the family, by identifying adoption communication patterns and analysing the impact of the variables related to the adoption process, the adoptive parenting and the adoptee. A better knowledge of the factors involved in the development of adoption communication openness will bring solid scientific basis to professional practices, both in the preparation for adoptive parenting, as well as in post adoption follow up.

\section{Method \\ Participants}

One hundred and twenty-five adoptive parents participated in this study, 95 mothers and 30 fathers, mutually independent of one other. They were aged between 31 and 59 years old $(M=43.58, S D=5.34)$ and their schooling was 13.28 years, on average $(S D=4.58$, range $4-22)$. The participant parents adopted 125 children (76 boys and 49 girls), when they were 0 to 12 years old $(M=3.45$, $S D=2.42)$. These children, aged 3 to 15 years $(M=8.02$, $S D=2.98$ ) were in the adoptive family for 4.58 years on average $(S D=2.42$, range $0.5-12.5)$. All these children had a past of adversity and were domestically adopted from 1998 to 2009, through the Portuguese Welfare System.

\section{Instrument and measures}

Parents' Interview on the Adoption Process [Entrevista sobre o Processo de Adoção (EPA)]. The Portuguese EPA (Palacios et al., 2013) is a semi-structured interview, composed of 124 questions. This interview followed the adoption process itself, covering different adoption themes, namely the reasons and processes of adoption decision making; the waiting period; the child's proposal and information regarding the child's past; the transition into the adoptive family; the child's arrival at the adoptive home; the child's adaptation and development; the child placed within the adoptive family; the communication about adoption; the adoption social disclosure; the attitudes towards adoption and the future and self-evaluation of adoption. The interview included open-ended questions ("How did you tell the child that he/she had been adopted?"), Yes-No questions ("Have you ever spoken to him/her about being adopted?") and 4-point Likert scale questions ("If you had to evaluate the way you 
dealt with this situation, would you say that you feel..." - level of satisfaction). The variables related to the adoption decision making process and adoption communication, such as frequency and openness in communication, parents' behaviours, emotions and ideas regarding adoption communication and child's adoption communication behaviours were measured by specific EPA interview questions. A new variable was computed in order to calculate the time period from the child's placement to the first communication/ revelation about adoption. This variable - communication timing - was gauged by calculating the difference between the child's age in the first communication/revelation and the child's age at placement $\quad($ Timing $=$ Age at revelation - Age at placement). In this calculus the variable related to age of placement was recoded by considering 2.5 years of age for all the children who were adopted prior to this time, because it is highly recommended to begin the adoption communication process at this age (e.g. Brodzinsky et al., 1984). The higher the communication timing, the longer was the time period until the first adoption communication within the adoptive family.

\section{Procedures}

\section{Sample selection}

This study is part of the IPA Project - Research on the Adoption Process: Parents' and Children's Perspectives [Investigação sobre o Processo de Adoção: Perspetiva de Pais e Filhos], which was approved by the University's Ethics Committee. For this project participant families were selected according to: (1) adoptive families whose legal adoption was more than half a year ago, i.e. the adoptee had been part of the family for at least a year, because in Portugal legal adoption is only considered after at least 6 months of life in common, and (2) families with adoptees between the ages of 3 and 15. All participant families in this Project are included in this study. Bearing in mind the ethical code of confidentiality ruling adoptive families, the first contact asking for cooperation was made by the adoption professionals in public agencies who had been responsible for the family file. All eligible families who were invited and voluntary agreed to participate were included in study.

\section{Data collection}

The interviews were held at home by qualified adoption researchers. The parents were previously asked to give their written consent. The interview lasted for 95.71 minuts, on average ( $S D=28.51$, range $45-180)$, and was aimed at the parent who considered him/herself closest to the child.

\section{Data analysis}

The data were analysed quantitatively by using descriptive statistical analysis, variance analysis (test post hoc of Turkey) and cluster analysis. In order to identify missing values, outliers, the normality of the distributions and the homogeneity of the variances, an exploratory analysis was previously made. To define the clusters, a mixed hierarchical and non hierarchical (K-means) procedure was used and the similarity of the participants was measured by Euclidean distance. Because this distance is considered sensitive to the scale measure of the variables, standardized variables were therefore used. By using the hierarchical method, the centroids were identified and the ideal number of clusters was explored to define the clusters by the non-hierarchical procedure.

\section{Results}

\section{Adoption communication: descriptive analysis}

Seventy-nine percent of the participants $(n=99)$ had spoken to their children about adoption. Nevertheless, in 26 families none of the children knew about their adoption. A significant difference, $t(123)=4.11, p<.001$, $d=0.93,95 \%$ CI $[1.32,3.77]$, was found between the average age of the children who already knew about their adoption $(M=8.55, S D=2.86$, ranging from 3 to 15 years) and those who did not know $(M=6.00$, $S D=2.62$, ranging from 3 to 13 years). Regarding the 99 children who knew they were adopted, the first family communication was the revelation of adoption, in $69 \%$ of the cases $(n=68)$, and had happened before the age of six, on average. The rest of the children were adopted at an age in which they were already aware of their situation and the first family communication focused on different topics related to their past history/story and the adoption itself. Table 1 presents the frequency of the family communication about adoption as being relatively low. Parents did not speak much about adoption and children asked very few questions. Nevertheless, outside the family there was more openness and the topic was discussed at school, with friends and neighbours. The communication timing was considered overdue, since it was, on average, beyond 2 years.

Table 1 Adoption Communication: Descriptive analysis

\begin{tabular}{lllll}
\hline & $M$ & SD & Min. & Max. \\
\hline Child's age at first communication & 5.85 & 2.42 & 2.5 & 12.5 \\
Communication timing (years) & 2.38 & 2.07 & 0 & 9.5 \\
Frequency of the parents' communication & 1.57 & 1.02 & 0 & 3 \\
Frequency of the child's questioning & 1.19 & 0.98 & 0 & 3 \\
Frequency of parent-child & 1.38 & 0.92 & 0 & 3 \\
communicative interaction & & & & \\
Adoption social disclosure & 3.16 & 0.67 & 1 & 4 \\
\hline
\end{tabular}




\section{Adoption communication: clusters analysis}

Three clusters were identified, considering three variables related to adoption communication, namely, communication timing, frequency of parent-child communicative interaction and social disclosure of adoption. The means of these variables were compared in the three clusters by using a one way analysis of variance (see Table 2). The three clusters showed significant differences in the three communication variables, with a moderate effect size (Cohen, 1988). Thus, the three clusters were composed of three types of families according to the level of adoption communication openness. Cluster 1 included families with a notably delayed communication timing, a markedly closed intrafamily communication, which was almost inexistent, and medium levels of social disclosure. Families belonging to Cluster 1 were, therefore, significantly different from those within Clusters 2 and 3. The families belonging to Cluster 2 showed a significantly more open and timely adoption communication, both within the family and the outside world, when compared to the families in Cluster 1. Cluster 3 was composed of the families who were the most open, within and out of the family, and whose communication timing was more timely, yet not significantly different from Cluster 2 .

\section{Openness communication and adoption process}

The three clusters were significantly different regarding some variables related to the adoption process. The easiness of decision making about adoption (evaluated on a 4-point Likert scale) was significantly different in the three groups, $F(2,122)=3.00, p=.049, \eta^{2}=0.05$. Cluster 1 , showing closed and delayed communication, presented lower values of easiness in decision-making, $(M=2.78$, $S D=0.87, n=32)$, followed by Cluster $2(M=3.00$, $S D=0.66, n=51)$ and Cluster $3(M=3.19, S D=0.63$, $n=42$ ), which revealed a more open and timely adoption communication. There are significant statistical differences between Cluster 1 and Cluster 3, 95 \% CI $[-0.81,-0.01], p=.042$. These same differences were also found regarding the adopters' awaiting time for adoption, $F(2,122)=3.21, p=.044, \eta^{2}=0.05$. Participants belonging to Cluster 1 waited longer for the child $(M=3.52, S D=1.61, n=32)$, followed by participants in Cluster $2(M=3.08, S D=1.76, n=51)$ and Cluster $3(M=2.49, \quad S D=1.86, n=42)$, which was significantly different from Cluster $1,95 \%$ CI $[-2.00$, -0.05], $p=.037$.

There was a significant association between the spouse's reaction to the adoption decision (assessed by means of a nominal variable with three categories: comply, accept or hesitate) and the three clusters, $\chi^{2}(4)=9.86, p=.043, V=0.26$. The spouses who complied belonged essentially to Cluster 3 , who showed more open communication. The spouses who accepted the adoption project proposed by his/her partner were found in Clusters 1 and 2. Spouses who hesitated were mainly in Cluster 1 , whose adoption communication was closed and delayed. In this cluster there were also more participants who considered forsaking the adoption, during the awaiting period. In Clusters 2 and 3 there were more participants, than those expected, who did not consider interrupting the adoption process, $\chi^{2}(2)=6.16, p=.046, V=0.22$.

The support and counselling, about adoption communication, provided by professionals to prospective adopters during the adoption process, were also associated to the clusters, $\chi^{2}(6)=14.25, p=.027, V=0.25$. The participants who were given concrete strategical indications about adoption communication were mainly found in Cluster 3 , whereas those who were given simple recommendations mostly belonged to Cluster 2 .

\section{Communication openness and parenting}

Table 3 presents parenting variables related to adoption communication behaviours, feelings towards adoption communication and adoption communication beliefs and cognitions, according to the three clusters. In terms of behaviours, the frequency of communication with the spouse about problems was higher in Cluster 3, which was significantly different from Cluster 1 . In relation to feelings, Cluster 2 and Cluster 3 are significantly different, seeing that the parents in Cluster 3 spoke more easily about the child's origins and showed more positive feelings towards the child's birth family. Regarding beliefs, all three clusters were significantly different. Participants in Cluster 3 showed less unfavourable beliefs about communication openness.

\section{Openness communication and child variables}

The child's age was different in the three groups, $F(2,122)=6.07, p=.003, \eta^{2}=0.09$. Cluster 1 included

Table 2 Adoption Communication: Cluster Analysis

\begin{tabular}{|c|c|c|c|c|c|}
\hline & Cluster $1(n=32)$ & Cluster $2(n=51)$ & Cluster $3(n=42)$ & $F(2,122)$ & $\eta^{2}$ \\
\hline Communication timing (years) & $5.03 \mathrm{a}$ & $1.70 \mathrm{~b}$ & $1.20 \mathrm{~b}$ & $83.78^{*}$ & 0.58 \\
\hline Frequency of parent-child communicative interaction & $0.17 a$ & $1.38 \mathrm{~b}$ & $2.30 \mathrm{c}$ & $211.88^{*}$ & 0.78 \\
\hline Adoption social disclosure & $2.45 \mathrm{a}$ & $3.14 b$ & $3.71 \mathrm{c}$ & $66.25^{*}$ & 0.52 \\
\hline
\end{tabular}

Notes: Different letters represent differences between clusters $(p<.001)$. According to Cohen (1988): $\eta^{2}>0.5-$ very large effect size $* p<.001$ 
Table 3 Clusters of Adoption Communication and Parenting - ANOVAs

\begin{tabular}{|c|c|c|c|c|c|c|}
\hline & Cluster $1 \mathrm{M}$ & Cluster $2 M$ & Cluster $3 \mathrm{M}$ & F & $p$ & $\eta^{2}$ \\
\hline Behaviours & $(n=32)$ & $(n=48)$ & $(n=39)$ & $(2115)$ & & \\
\hline Frequency of communication with spouse about problems & $2.97 \mathrm{a}$ & $3.29 a, b$ & $3.41 \mathrm{~b}$ & 4.06 & .02 & 0.07 \\
\hline Feelings & $(n=32)$ & $(n=51)$ & $(n=42)$ & $(2122)$ & & \\
\hline Easiness in talking about child's origins & $2.25 \mathrm{a}$ & $2.53 \mathrm{a}$ & $2.93 \mathrm{C}$ & 10.31 & $<.001$ & 0.15 \\
\hline Positive feelings toward child's birth family & $2.75 \mathrm{a}, \mathrm{b}$ & $2.68 \mathrm{a}$ & $2.92 \mathrm{~b}$ & 4.91 & .009 & 0.07 \\
\hline Cognitions & $(n=30)$ & $(n=49)$ & $(n=41)$ & $(2117)$ & & \\
\hline Unfavourable beliefs about communication openness & $2.23 \mathrm{a}$ & $1.88 \mathrm{~b}$ & $1.60 \mathrm{C}$ & 12.49 & $<.001$ & 0.18 \\
\hline
\end{tabular}

Notes: Different letters represent differences between clusters $(p<.001)$. These variables were measured on a 4-point scale. According to Cohen (1988): $\left.\eta^{2}\right]$ 0.05 0.25] - moderate effect size

younger children $(M=6.66, S D=2.94, n=32)$, followed by Cluster $2(M=8.06, S D=2.82, n=51)$ and finally Cluster $3(M=9.00, S D=2.87, n=42)$, with older children. Cluster 1 and Cluster 3 are significantly different, $95 \%$ CI [$3.94,-0.75], p=.002$. Gender also appeared associated with the development of adoption communication openness, $\mathrm{X}^{2}(2)=8.00, p=.02, V=.25$ : males had a higher probability of belonging to Cluster 1 and females had a higher probability of belonging to Cluster 2 or 3 . According to the parents' perspective, the child's behaviours were relatively different in relation to adoption communication openness. Table 4 shows the significant associations between the child's behaviour regarding adoption communication, according to the parents' perspective, and the respective clusters. This table presents the real number of participants in each cluster, as well as the expected one. Children in Cluster 1 and 2 have a more closed and passive behaviour than the one expected, whereas children in Cluster 3 have a more opening and active behaviour in adoption communication within the family.

\section{Discussion}

This study aimed at exploring the process of adoption communication openness in the participating families. Data showed differences between the families along an adoption communication openness continuum, ranging from families with strictly closed communication (the child did not know he/she had been adopted), families who just simply revealed the adoption status, to other families with an open and frequent adoption communication. The results showed the complexity of this phenomenon (adoption communication as being both universal and specific at the same time), which differed according to each family. Furthermore, results also highlighted the difficulty that some participating parents had in managing this task and in understanding adoption communication as a process rather than a single moment in time. Revealing adoption is only a small part of the adoption communication process which involves, not only the act of sharing the information, but also the feelings, doubts, frustrations and joys that the adoptee and adopters may naturally feel about their adoption status (Palacios, 2012).

Table 4 Associations between Clusters and Child's Behaviours towards Adoption Communication

\begin{tabular}{|c|c|c|c|c|c|c|c|}
\hline & & Cluster 1 & Cluster 2 & Cluster 3 & $x^{2}(2)$ & $p$ & V \\
\hline \multirow[t]{2}{*}{ The child refuses to talk about adoption } & $n$ & 2 & 16 & 1 & 13.31 & .001 & 0.37 \\
\hline & Exp. & 1.2 & 9.8 & 8.1 & & & \\
\hline \multirow[t]{2}{*}{ The child never initiates a conversation about adoption } & $n$ & 3 & 21 & 4 & 12.86 & .002 & 0.36 \\
\hline & Exp. & 1.7 & 14.4 & 11.9 & & & \\
\hline \multirow[t]{2}{*}{ The child doesn't show curiosity about adoption or the past } & $n$ & 4 & 30 & 6 & 20.80 & $<.001$ & 0.46 \\
\hline & Exp. & 2.4 & 20.6 & 17 & & & \\
\hline \multirow[t]{2}{*}{ As the child was growing up, more questions were asked } & $n$ & 0 & 13 & 21 & 9.48 & .009 & 0.31 \\
\hline & Exp. & 2.1 & 17.5 & 14.4 & & & \\
\hline \multirow[t]{2}{*}{ The child talks easily about adoption } & $n$ & 2 & 30 & 37 & 13.34 & .001 & 0.37 \\
\hline & Exp. & 4.2 & 35.5 & 29.3 & & & \\
\hline \multirow[t]{2}{*}{ The child speaks frequently about adoption } & $n$ & 0 & 4 & 11 & 7.17 & 0.28 & 0.27 \\
\hline & Exp. & 0.9 & 7.7 & 6.4 & & & \\
\hline
\end{tabular}


Frequency of the communicative interaction between parents and children was low, and there was a cycle of closed communication, as mentioned by Palacios and Sanchez-Sandoval (2005): parents do not talk because children do not ask questions and children do not ask questions because they do not feel enough communication openness on behalf of the parents.

Results also highlighted the relevance of prior preparation and training for prospective adopters. It should be referred that in Portugal adoption preparation was only instilled in 2010 and only now has it become compulsory by law. Nevertheless, it should be said that the participants in this study did not have any training because they adopted prior to 2009. Adoption professionals should prepare prospective adopters for the complexity of this process and promote their skills in order to understand the importance of answering to the adopted child's needs, besides managing this adoption communication process, which as referred by Brodzinsky (2005), does not just depend on the amount of existing information about the child's past. It should be possible to talk about what is known, as well as, what is not known when searching for answers as a family. This study found that simple recommendations or rather concrete communication strategies given to prospective adopters were associated to different levels of adoption communication openness later within the family. These types of professional intervention were part of the assessment and selection process and not of training programmes, as above mentioned.

Furthermore, data revealed that parents postponed adoption revelation to the time when children started school. Possibly they were afraid that, once at school, the child would be told about his/her adoption by someone else. These same results could be better explained according to contextual variables. The community's acceptance and social insight on adoption can influence the process of adoption communication openness within the family. Similar to what happens in Brazil (Maux \& Dutra, 2010; Merçon-Vargas et al., 2014), in Portugal it is also seen as an "alternative", "second best" option and the birth family is still described as the "natural family" and birth parents are still seen as "real parents". Adoption language is full of myths and stereotypes, displaying differential and discriminatory treatment of adoptive families, adopters and adoptees. Future research should consider the role played by contextual variables related to adoption social beliefs in order to explain the process of adoption communication openness.

This study allowed for the identification of three different groups of families, within the heterogeneity of the participating adoptive families, according to adoption communication openness. Two groups at opposing ends showed contrasting characteristics (Clusters 1 and 3) and the third intermediate group presented particular features (Cluster 2). Cluster 1, titled Delayed and Closed Adoption Communication, was composed of the families who had more difficulty in adoption decision-making (having hesitated), who waited longer for the child, who considered backing out during the awaiting time, who found it more difficult to talk to his/her spouse about problems, who were challenged in speaking about the child's birth family and who revealed more unfavourable beliefs about adoption communication openness. The children belonging to these families were younger and most of them were male. Cluster 2, called Timely and Opening Adoption Communication, was characterised by a timely communication timing, showing a kind of communication which was not totally flowing nor highly frequent. This intermediate group stood out from the others regarding the lack of empathy felt towards the birth family by showing less positive feelings in this respect. Since the adoptees in Cluster 1 did not know they had been adopted, it was the ones belonging to Cluster 2 who presented more closed adoption communication. Cluster 3, labelled Timely and Open Adoption Communication, included the families who found it easier to decide in favour of adoption, who waited less for the child, who did not consider backing out of the process during the awaiting time, who received concrete strategies on adoption communication provided by professionals, who talked more openly about problems as a couple, who spoke more easily about the child's origins, who showed more empathy towards the birth family and who presented less unfavourable beliefs about adoption communication openness. These were families who achieved a higher level of adoption communication openness and consequently the children belonging to these families, who were older and mostly female, showed more open adoption communication behaviours, higher curiosity and were able to speak more easily and frequently about adoption.

These results support the understanding that adoption communication is a developmental process which does not only start at the child's arrival to the family, but rather evolves throughout the adoption process from the moment the parents decide to adopt. This study allowed for the definition of indicators in adoption communication openness which were evident along the adoption process. These indicators are related to the adoption decision-making, as well as the adoption process itself, seeing that a higher awaiting time normally corresponded to the wish for younger children or even a lower level of parenting skills in order to answer responsively to the child's needs. Furthermore, the results highlight that adoption communication is essentially an interactive process as stated by Le Mare and Audet (2011). Both parents and children interact in the 
promotion of the adoption communication openness. The adoptees who were more curious and spoke more openly about adoption belonged to families in which parents also communicated more openly as a couple about everything and where there was more empathy towards the adoptee's origins and life story. In other words, adoption communication is a dynamic developmental process whose openness is strengthened through parent-child interaction. Furthermore, it can also be related to other variables regarding the family interaction and dynamics, such as attachment, general communication patterns, socio-emotional competence and reflective functioning. These have not been studied in this paper, but could eventually explain this process and be included in future research.

The results also show that some variables related to the adoption process and parental behaviour are associated to the development of the adoption communication openness and can be changed with the help of skilled professionals. It should also be pointed out that this process can be redeemed in any phase of the adoptive families' life span. This is true even for families with a delayed and more closed communication who can develop a better level of adoption communication openness, through skilled professional intervention. Consequently, the results translate into adoption policies and professional practices, not only in terms of the relevance of prospective adopters' training, but also in terms of designing evidence-based adoption practices. For maximum efficiency, professional intervention should break the boundaries of the work done only with prospective adopters and adoptive families and take on a larger social context which favours a change in the social image of adoption, as recommended by Maux and Dutra (2010).

\section{Conclusion}

Finally it should be specified that the analysis of the process of adoption communication openness which is presented in this paper, only includes the parents' perspective. This is obviously one of the limitations of this study. Future research should consider the child's view point in the analysis of the variables approached in this study. Moreover, variables related to adoption communication should also be analysed qualitatively, for example in terms of physical and emotional availability to talk about the subject, emotional attunement and narrative coherence of the discourse. These variables should not be limited to quantitative indicators of communication frequency. In spite of these limitations, this study approaches the process of adoption communication openness in adoptive families, which empirically supports the development of professional intervention in order to promote adoption communication openness.
Competing interests

The authors declare that they have no competing interests.

\section{Author's contributions}

Research, data collection, analysis and writing of the manuscript were joint contributions of both authors. Both authors read and approved the final manuscript.

Received: 9 March 2016 Accepted: 7 April 2016

Published online: 14 April 2016

\section{References}

Barbosa-Ducharne M, Barroso R. Análise intergeracional do processo de adoção: Avós, pais e filhos [Intergenerational analysis of the adoption process: Grandparents, parents and children]. AMAzônica: Revista de Psicopedagogia, Psicologia Escolar e Educação [Amazónica: Journal of Psychopaedogogy, School Psychology and Education]. 2012; 8(1): 185-209. Retrieved from: http://hdl.handle.net/10216/63869

Barbosa-Ducharne M, Ferreira J, Soares J. Communication openness in the adoptive family and the psychological adjustment of adoptees. In: Proceedings of the XV European Conference on Developmental Psychology. Roma: Medimond; 2012b. p. 215-24.

Barbosa-Ducharne M, Ferreira J, Soares J, Barroso R. Parental perspectives on adoption communication within Portuguese adoptive families: Children/ adolescents. Family Science. 2015;6(1):58-67. doi:10.1080/19424620.2015. 1080994.

Barbosa-Ducharne M, Soares J, Ferreira J. Comunicação pais-filhos sobre adoção e desenvolvimento da compreensão do conceito de adoção [Parent-children adoption communication and adoption understanding development]. In: Lopes J, Pinheiro M, Brandão MC, Dias P, Sampaio R, editors. Atas do IV Encontro sobre Maus Tratos, Negligência e Risco na Infância e Adolescência [Proceedings of the IV Meeting on Abuse, Negligence and Risk in Childhood and Adolescence]. Maia: ASAS; 2011. p. 45-9.

Brodzinsky DM. A stress and coping model of adoption adjustment. In: Brodzinsky DM, Schechter MD, editors. The psychology of adoption. New York: Oxford University Press; 1990. p. 3-24.

Brodzinsky DM. Reconceptualizing openness in adoption: Implications for theory research and practice. In: Brodzinsky D, Palacios J, editors. Psychological issues in adoption: Research and practice. New York: Greenwood; 2005. p. 145-66.

Brodzinsky DM. Family structural openness and communication openness as predictors in the adjustment of adopted children. Adopt Q. 2006;9(4):1-18. doi:10.1300/J145v09n04_01.

Brodzinsky DM. Children's understanding of adoption: developmental and clinical implications. Prof Psychol Res Pract. 2011;42(2):200-7. doi:10.1037/a0022415.

Brodzinsky DM, Singer LM, Braff AM. Children's understanding of adoption. Child Dev. 1984;55:869-78. doi:10.1111/1467-8624.ep12424986.

Cohen J. Statistical power analysis for the behavioral sciences. Hillsdale: Lawrence Erlbaum Associates; 1988.

Departamento de Desenvolvimento Social e Programas do Instituto de Segurança Social, Instituto Público [Departement of Social Development and Programmes of the Institute of Social Security, Public Institute] DSSP do ISS, IP. Adoção Nacional e Internacional. Relatório 2013 [Domestic and Intercountry Adoption Report 2013]. Lisboa: DSSP do ISS, IP; 2014.

Decreto-lei [Act] 12/98 de 8 de Maio [of $8^{\text {th }}$ May].

Decreto-lei [Act] 185/93 de 22 de Maio [of 22 ${ }^{\text {nd }}$ May].

Decreto-lei [Act] 274/80 de 13 de Agosto [of $13^{\text {th }}$ August].

Farr RH, Grant-Marsney HA, Grotevant HD. Adoptees' contact with birth parents in emerging adulthood: The role of adoption communication and attachment to adoptive parents. Fam Process. 2014;53(4):656-71. doi:10.1111/famp.12069.

Grotevant HD, Perry Y, McRoy RG. Openness in adoption: Outcomes for adolescents within their adoptive kinship networks. In: Brodzinsky D, Palacios $J$, editors. Psychological issues in adoption: Research and practice. New York: Greenwood; 2005. p. 167-86.

Grotevant HD, Ruetter M, Von Korff L, Gonzalez C. Post-adoption contact, adoption communicative openness, and satisfaction with contact as predictors of externalizing behavior in adolescence and emerging adulthood. J Child Psychol Psychiatry. 2011;52:529-36. doi:10.111/j. 1469-7610.2010.02330.x. 
Hawkins A, Beckett C, Rutter M, Castle J, Colvert E, Groothues C, et al. Communicative openness about adoption and interest in contact in a sample of domestic and intercountry adolescent adoptees. Adopt Q. 2007:10(3-4):131-56. doi:10.1080/10926750802163220.

Howe D, Feast J. Adoption, search and reunion: The long-term experience of adopted adults. London: BAAF; 2003.

Instituto de Segurança Social, Instituto Público [Institute of Social Security, Public Institute] ISS, IP. CASA 2014 - Caracterização Anual da Situação de Acolhimento das Crianças e Jovens [CASA 2014 - Annual Caracterization of Children' and Youth's Out-of-home Care]. Lisboa: ISS, IP; 2015.

Juffer F, Palacios J, LeMare L, Sonuga-Barke E, Tieman W, Bakermans-Kranenburg M, et al. Development of adopted children with histories of early adversity. Monogr Soc Res Child Dev. 2011;76:31-61. doi:10.1111/j.1540-5834. 2011.00627

Kirk HD. Shared fate: A theory and method of adoptive relationships. New York: Free Press; 1964.

Kohler JK, Grotevant HD, McRoy RG. Adopted adolescents' preoccupation with adoption: The impact on adoptive family relationships. J Marriage Fam. 2002;64:93-104. doi:10.1111/j.1741-3737.2002.00093.x.

Le Mare L, Audet K. Communicative openness in adoption, knowledge of culture of origin, and adoption identity in adolescents adopted from Romania. Adopt Q. 2011;14(3):199-217. doi:10.1080/10926755.2011.608031.

Lei [Law] 31/2003 de 22 de Agosto [of $22^{\text {nd }}$ August].

Lei [Law] 143/2015 de 8 de setembro [of $8^{\text {th }}$ September].

Levy-Shiff R. Psychological adjustment of adoptees in adulthood: Family environment and adoption-related correlates. Int J Behav Dev. 2001;25(2):97-104. doi:10.1080/01650250042000131.

Macintyre JC. Debate forum: Resolved: Children should be told of their adoption before they ask: positive. J Am Acad Child Adolesc Psychiatry. 1990;29(828-829):832-3

Maux A, Dutra E. A adoção no Brasil: Algumas reflexões [Adoption in Brazil: Some reflections]. Estudos e Pesquisas em Psicologia [Studies and Research in Psychology] 2010; 2: 356-72. Retrieved from: http://www.revispsi.uerj.br/ v10n2/artigos/pdf/v10n2a05.pdf

Merçon-Vargas EA, Rosa EM, Dell'Aglio DD. Adoção nacional e internacional: Significados, motivações e processos de habilitação [Domestic and intercountry adoption: Meanings, motivations and qualification processes]. Revista da Sociedade de Psicoterapias Analíticas Grupais do Estado de São Paulo [Journal of the Society of Group Analitic Psychoterapies of the State of São Paulo]. 2014;15(2):12-26. Retrieved from: http://pepsic.bvsalud.org/pdf/ rspagesp/v15n2/v15n2a03.pdf.

Neil E. Post-adoption contact and openness in adoptive parents' minds: Consequences for children's development. Br J Soc Work. 2009;39:5-23. doi:10.1093/bjsw/bcm087.

Palacios, J. Familias adoptivas [Adoptive families]. In E. Arranz \& A. Oliva (coord.) Desarrollo psicológico en las nuevas estructuras familiars [Psychological development in new family structures], Madrid: Ed. Pirâmide; 2010 p. 51-67.

Palacios J. Adopción: identidad o identidades? [Adoption: Identity or identities?]. Cidade Solidária [Solidarity City]. 2012;15(27 e 28):86-91.

Palacios J, Brodzinsky D. Adoption research: Trends, topics, outcomes. Int J Behav Dev. 2010:34:270-84. doi:10.1177/0165025410362837.

Palacios J, Sanchez-Sandoval Y. Beyond adopted/non-adopted comparisons. In: Brodzinsky D, Palacios J, editors. Psychological issues in adoption: Research and practice. New York: Greenwood; 2005. p. 117-44.

Palacios J, Sanchez-Espinosa E, Sanchez-Sandoval Y, Barbosa-Ducharne M, Moreira A, Ferreira da Silva A, Monteiro J, Soares J. EPA: Entrevista sobre o Processo de Adoção [EPA: Parents' Interview on the Adoption Process]. In J. A. Lima, M. Serra de Lemos, A Gamelas (Eds.) Instrumentos de investigação desenvolvidos, adaptados ou usados pelo Grupo de Investigação Desenvolvimental, Educacional e Clínica com Crianças e Adolescentes [Research instruments developed, adapted or used by the Developmental, Educational and Clinical Research with Children and Adolescents Group]. Porto: FPCEUP; 2013; p.117-21.

Sequeira VC, Stella C. Preparação para a adoção: grupo de apoio para candidatos [Adoption preparation: Support group for prospective adopters]. Revista Psicologia: Teoria e Prática [Psychology Journal: Theory and Practice]. 2014; 16(1): 69-78. Retrieved from http://pepsic. bvsalud.org/pdf/ptp/v16n1/06.pdf van IJzendoorn MH, Juffer F. The Emanuel Miller memorial lecture 2006: Adoption as intervention. Meta-analytic evidence for massive catch-up and plasticity in physical, socio-emotional and cognitive development. J Child Psychol Psychiatry. 2006;47:1228-45. doi:10.1111/j.1469-7610.2006.01675.x.

Wydra M, O'Brien K, Merson E. In their own words: Adopted persons' experiencies of adoption disclosure and discussion in their families. J Fam Soc Work. 2012;15(1):62-77. doi:10.1080/10522158.2012.642616.

Wrobel GM, Kohler JK, Grotevant HD, McRoy RG. The family adoption communication (FAC) model: Identifying pathways of adoption related communication. Adopt Q. 2003;7(2):53-84. doi:10.1300/J145v07n02_04.

\section{Submit your manuscript to a SpringerOpen ${ }^{\circ}$ journal and benefit from:}

- Convenient online submission

- Rigorous peer review

- Immediate publication on acceptance

- Open access: articles freely available online

- High visibility within the field

- Retaining the copyright to your article

Submit your next manuscript at $>$ springeropen.com 